\title{
Heinrich Ursprung: a scholarly life
}

\author{
Arye L. Hillman ${ }^{1}$
}

Published online: 10 October 2021

(c) The Author(s), under exclusive licence to Springer Science+Business Media, LLC, part of Springer Nature 2021

\section{Bravery}

Heinrich Ursprung, often simply called Henry, who left us in an untimely manner in August 2021, just short of his 70th birthday, was a leading European public-choice scholar and a former president of the European Public Choice Society. Henry was Swiss. He lived in Switzerland and commuted a short distance across the border to the University of Konstanz in Germany. Konstanz is contiguous with the Swiss city of Kreuzlingen. The story is told that, during World War II, the residents of Konstanz left their lights on so that it would be unclear where Switzerland ended and Germany began, and a beautiful mediaeval town was spared allied bombing. The University of Konstanz is outside the mediaeval town but sufficiently close to Switzerland for Henry in good weather to go by bicycle to the officea traditional bicycle relying on human effort. Henry was the quintessential scholar. He read widely and thought before he ventured an opinion. He was a student of Peter Bernholz of the University of Basel, who initiated appreciation of public choice in Europe. Opposition to public choice in Europe, as in the United States, came from believers in the need for government to correct or replace markets. In Europe, socialism and market interventionism have not been hidden, as has been the case in the United States, behind a façade of terms such as "liberal" and "progressive". One had to be brave in Europe to go against an embedded mainstream. Peter Bernholz was brave. He imparted his bravery to Henry.

\section{Modelling democracy}

Henry was as good a theorist as could be found anywhere. An area of his expertise was the theory of political competition (Ursprung, 1991). Models of political competition acknowledge the existence of politicians. In contrast, when mainstream economists first turned their attentions to policy determination, the median-voter model, which does not include politicians, tended to be adopted. Henry believed omission of politicians in policy modelling to be inappropriate. Politics involves politicians and political discretion. He felt that, through the median-voter model, direct democracy was being adopted to describe policy determination in countries that were representative democracies or barely democratic. Was

Arye L. Hillman

arye.hillman@biu.ac.il

1 Bar-Ilan University, 5290002 Ramat Gan, Israel 
the reason for reliance on the median-voter model that direct democracy dispenses with the need to talk about politicians and the policy discretion they exercise?

Moreover, if a direct-democracy model is going to be applied, there is no necessity that the rich will be in the minority. An insightful paper (Breyer \& Ursprung, 1998) considered majorities based on high-income voters forming coalitions with voters between the mean and median in the income distribution. It was also observed that in principle the rich could form a majority coalition with the poor and exclude the median voter.

The political-competition model could be applied to explain how candidates choosing policies in response to campaign contributions would exhibit a preference for creating foreign cartels that would restrict imports, rather than imports being restricted through traditional protectionist tariffs (Hillman \& Ursprung, 1988). The model could be applied to explain the influence of multinational firms on trade policy (Hillman \& Ursprung, 1993). The political-economy theme in trade policy gained prominence when a rent-extracting politician was modelled as "selling" protectionist policies. Henry could sympathize with a view of politicians as using policies to create rents that could be extracted as benefits for themselves. He believed, however, that rent-extracting policies for political benefit bordered on corruption. He was interested in democracies in which candidates offered voters policy alternatives through political competition, and not in politicians making the first move in a game by offering to "sell" policies to special interests. ${ }^{1}$

When accepting an invitation to present a paper on the environment and trade policy in Geneva, the political-competition model could again be applied, now in the context of coalitions (Hillman \& Ursprung, 1992, 1994). ${ }^{2}$ Predictions depended on whether environmentalists were concerned only with environmental quality in their localities (not-in-mybackyard "nimbies") or cared about the environment in the world at large. Henry coined the terms "greens" and "supergreens" to describe the two different types of environmentalists. Greens were not bothered by polluting industries located far away and were quite happy to consume foreign-produced pollution-creating imported goods under a policy of free trade. Supergreens objected to polluting industries anywhere and favored protectionist trade policies to weaken the incentives for foreign pollution-creating production including through outsourcing of polluting activities to foreign locations. Environmentalists thus could be the allies in trade policy of either protection-seeking producers or liberal-tradepolicy-seeking consumers. There were objections to the model. Were objections related to the conclusion that whether environmentalists had an interest in supporting free trade or protectionism depended on whether they were "greens" or "supergreens"? In demonstrations against the GATT or the WTO, the World Bank and IMF, the protestors' claim was that the international institutions were betraying humanity by supporting the creation of markets. The protestors wanted protectionism to close down international markets. The interest of nimbies had however been shown to be the converse: free trade. Nimbies participating in anti-market demonstrations were on the wrong side in countering their own selfinterest. There is no evidence that nimbies cared. In retrospect, perhaps the demonstrations, which could turn violent, were not about trade and markets, but were an early beginning of attempted "woke" subversion of market-based western civilization.

\footnotetext{
1 Another earlier political-economy approach did not view incumbent politicians as extracting rents for personal benefit but as maximizing political support. Political competition was implicit.

2 At the GATT, replaced by the World Trade Organization.
} 


\section{Collaboration and independence}

A close professional and personal collaborative relationship began when Henry and I were both at UCLA between 1985 and 1987. From UCLA, Henry moved to the University of Konstanz and I returned to Bar-Ilan University in Israel from whence I had come for an extended sabbatical. In 1994, we shared the Max Planck Prize for Humanities Sciences. In the same year, we began editing the European Journal of Political Economy. Our co-editorship was to continue for two decades. The EJPE had been founded by Manfred Holler of the University of Hamburg in protest against perceived discriminatory treatment at the American Economic Review. He had submitted a paper that he was told by the editor was not on a topic of interest, but then, not long afterwards, a paper appeared on precisely the same topic. Manfred proceeded to establish the EJPE. We took over from Manfred when Elsevier became the publisher. The original protest motive for the journal was appealing. We sought to give authors fair hearings. If papers were desk-rejected, the reason was made clear to authors, rather than sending a form letter with amorphous comments. An objective always was to improve a paper rather than dismissing ideas that could benefit from more attention. In the beginning, the EJPE was not included in the Social Science Citation Index and so had no impact factor. The "chicken and egg problem" that seemed an effective barrier to entry was that a journal's inclusion in the Index required publication of papers by "leading academics", who were, however, unwilling to submit their papers to journals not in the Index. Strategic thinking was required to overcome the obstacle. The EJPE entered the Citation Index and developed a good impact factor.

Henry initiated the Silvaplana workshop in 1989 to promote political-economy and public-choice perspectives, especially among students. The workshop format, which has been retained, is papers presented by students in the mornings and by senior faculty in the evenings; afternoons are taken up by mountain hikes that often are strenuous but during which conversation can take place. The workshop is rules-based. One rule is compulsory attendance. Presenters on the last day have the same audience as presenters at other sessions. The free-rider problem of conference participation is solved. Henry chose an esoteric location for the workshop, the region of Switzerland in which the Romansh language uniquely is spoken. Henry's last professional appearance was at the 30th workshop in July 2021.

The Silvaplana workshop and the EJPE opened an independent stream paralleling public-choice conferences and the Public Choice journal. We were not a subsidiary of the public-choice enterprise. Indeed, neither Henry nor I were ever on the editorial board of Public Choice. ${ }^{3}$ An independent voice for public-choice ideas contributed to countering an early version of "cancel culture" that seemed to have been in play in bastions of European socialism and interventionism. Henry did not accept the principles of the "left" but he was not on the "right". In European history, the "right" brings to mind oppressive autocratic regimes that are the very opposite of the democracies studied using the theory of political competition that Henry favored.

\footnotetext{
${ }^{3}$ Nor was Henry's mentor Peter Bernholz ever a board member. Like his student Henry, Peter Bernholz was eclectic in covering more than usual public-choice topics. A special issue of Public Choice in recognition of the scholarly achievements of Peter Bernholz was published in 2020. The papers were drawn from the Silvaplana workshop that had in the previous year been in his honor. See Hillman and Ursprung (2020).
} 


\section{The relevance of rents}

The 1990s were years of transition away from socialism. A model like political competition could be applied to propose that political liberalization explained the extensive rent seeking in the transition (Hillman \& Ursprung, 2000). In communist regimes, two rent-seeking contests had taken place simultaneously, with outsiders competing to become insiders, while insiders competed for the rents obtainable from privileged political and party positioning. Political liberalization allowed everyone to compete directly for rents. Rent seeking thus was predicted to increase when political liberalization took place. Did the prediction mean that political liberalization was undesirable? Not at all. The point was that, so long as rent seeking remained embedded in a society's culture, the economic benefits from political liberalization would be limited. In various other contexts as well, including trade policy and banking, political behavior in the transition made evident the contribution of rent seeking and other public-choice ideas in explaining events taking place. ${ }^{4}$

Rents, and insiders and outsiders, also feature in the phenomenon of migration from low to high-income countries. In a study with Gil Epstein (Epstein et al., 1999), written during one of Henry's regular visits to Bar-Ilan University, we described an authoritarian "king" extracting and redistributing rents among the population (the king also kept some rents for himself). How people fared depended on their locations on a direct line from the king, who typified any autocrat. People with comparative advantages in rent seeking were closer to the king and those with comparative advantages in productiveness further away. The population unraveled through adverse selection as the people furthest from the king at the end of the line left the country. We judged that the king would not leave and titled the paper "the king never emigrates". The model would not be well-received by believers in the necessity of only good government being portrayed in "developing countries", even if these countries were in fact not "developing", other than perhaps for the benefit of their autocratic rulers. The "politics of identity" imparts sensitivity to the model if all people in low-income countries, including political leaders, are required to be viewed as victims in a color-conscious world. Still, escape from rent-extracting government or from the "king" explains people emigrating in attempts to reach democracies where the rule of law prevails and where they will safe from predation.

Gordon Tullock had raised the question, in reference to high-income democracies, why less rent seeking is observed than the rent-seeking models predicted. More than one answer is possible (Hillman \& Ursprung, 2016a). Henry had proposed as a plausible explanation (Ursprung, 1990) that rent seeking was bounded at low levels when, as is expected in democracies, rent seeking predominantly is by interest groups, and policy-created rents provide collective or public-good benefits for interest-group members. Henry showed (Ursprung, 2012), adopting an evolutionary perspective, that cooperation in rent seeking will be displaced by behavior reflecting narrower personal incentives. In showing that to be the case, he set aside the usual incentives associated with public goods and free riding.

A vast literature testifies to rent seeking being a primary concept in explaining economic and political behavior (Congleton et al., 2008), but Gordon Tullock's paper

\footnotetext{
4 Alan Gelb, chief economist at the World Bank, joined a descriptive paper on "rents as distractions: why the exit from transition is prolonged" (Gelb et al., 1998). On Henry's collaborations on the political economy of trade liberalization during the transition, see Hillman and Ursprung (1996, 1999a, b) and Hillman et al. (1997). On the political economy of banking crises in the transition, see Hillman and Ursprung 1999c).
} 
originally pointing out the social cost of contestability of policy-created rents was rejected at the AER. Henry and I compared Tullock's experience with other cases of academic exclusion (Hillman \& Ursprung, 2016b). The rejection of Tullock's paper was at the hands of an editor who was an openly avowed Maoist. Around the same time that Tullock's paper was being rejected, the Maoist editor accepted an alternative idea that inefficiency owed to an unobservable $\mathrm{X}$ that translated into laziness. Coercion therefore was by inference justified to make people contribute according to ability, as Karl Marx and Mao required. How could an openly avowed Maoist come to edit the $A E R$ ? The question is rhetorical.

\section{Henry and the students}

Henry organized academic writing workshops for students. He was generous in sharing his ideas, in awareness that the most difficult part of a thesis can be defining the original idea that the thesis develops. After the onset of the twenty-first century, Henry tended to write with his students. He remained interested in trade and the environment (Kauder et al., 2018; Schulze \& Ursprung, 2001). He studied how regime type influenced foreign investment (Harms \& Ursprung, 2002): multinational firms had been criticized as favoring investment in locations with repressive regimes, but the study found on the contrary that multinational firms tended to invest in locations with civil and political freedom. He studied constitutional choice in a federation (Bodenstein \& Ursprung, 2005). He studied how "beauty" affected the placing of political candidates in electoral contests (Potrafke et al., 2020).

He was interested in globalization (Dreher et al., 2008; Harms \& Ursprung, 2002; Schulze \& Ursprung, 1999). In particular, he studied how globalization affected gender equality (Potrafke \& Ursprung, 2012). Globalization was found to be conducive to equality. Also, regarding gender, and reflecting on his interest in his daughters, he studied whether gender separation in schooling benefitted girls (Eisenkopf et al., 2015). The finding, based on Swiss data from random assignment of girls to coeducational and single-gender schooling, was that gender-separated classes improved girls' performances in mathematics and enhanced girls' self-confidence overall. The conclusion pointed to the behavior of boys in intimidating girls. He studied how being a parent affects productivity in academia (Krapf et al., 2017). A motherhood penalty was found for young single mothers and women having had more than one child, but the research outputs of untenured males increased after their first child was born. A paper with Dalila Lindov, Henry's last graduate student, found that successful women are successful, even if they have children (Lindov \& Ursprung, 2021).

Henry was interested in whether the chosen field of study influenced students' political attitudes (Fischer et al., 2017). The study of economics was found to make students more appreciative of the benefits of markets, while studying humanities and natural sciences reinforced anti-market views. In a paper under Henry's supervision, Dalila Lindov evaluated the political leanings of teachers, who in Germany were found to be distinctly on the left (Lindov, 2020). Henry's wide range of interests led him to study how a painter's death affected the prices of the painter's works (Ursprung \& Wiermann, 2011). In his final paper (Ursprung, 2021), Henry studied whether rare classic books are worthwhile investments. 


\section{Finality}

Henry Ursprung was a special intellectual. I have tried to provide an impression as to why that is so. He sought out objective truth. He was not distracted by majority-imposed restraint on what can be said. He had no patience for what is now called "woke" thought. He often would use humor to make a point. An anecdote illustrates. When two expatriate Harvard economists at a conference relied on the median-voter model to describe policy determination in a host of countries, Henry as discussant declared how pleased he was, being Swiss, that an Italian and a Turk living in America had used the political system of his country to describe policy determination around the world. Henry would often make his points in such an ironic but humorous way, in this case choosing to disregard progressive universal values, which in original Marxist form are sustained by the injunction that people should be viewed (and should view themselves) in an ahistorical way. I have not been able to, nor did it seem possible, to attempt to disentangle our cooperation in our joint projects over some 35 years. Henry did much outside of our cooperation. I have focused on Henry as an academic but his life was full in many dimensions. He was an avid skier, flew airplanes, played the violin, was past president of the local rotary club, and was a dedicated father and grandfather. More personal accounts of Henry are available (in the EJPE, and by his former students Hefeker \& Potrafke, 2021). His family and friends, and academic economics, and public choice in particular, will miss Henry. All that we can do is go on as he would have wanted us to do, keeping his memory alive.

\section{References}

Bodenstein, M., \& Ursprung, H. W. (2005). Political yardstick competition, economic integration, and constitutional choice in a federation. Public Choice, 124(3-4), 329-352.

Breyer, F., \& Ursprung, H. W. (1998). Are the rich too rich to be expropriated? Economic power and the feasibility of constitutional limits to redistribution. Public Choice, 94(1), 135-156.

Congleton, R. D., Hillman, A. L., \& Konrad, K. A. (Eds.). (2008). Forty years of research on rent seeking. Volume 1: The theory of rent seeking. Volume 2: Applications: Rent seeking in practice. Springer.

Dreher, A., Sturm, J. E., \& Ursprung, H. W. (2008). The impact of globalization on the composition of government expenditures: Evidence from panel data. Public Choice, 134(3-4), 263-292.

Eisenkopf, G., Hessami, Z., Fischbacher, U., \& Ursprung, H. W. (2015). Academic performance and single-sex schooling: Evidence from a natural experiment in Switzerland. Journal of Economic Behavior \& Organization, 115, 123-143.

Epstein, G., Hillman, A. L., \& Ursprung, H. W. (1999). The king never emigrates. Review of Development Economics, 3, 107-121. Reprinted in: R. D. Congleton, A. L. Hillman, \& K. A. Konrad (Eds.) (2008). Forty years of research on rent seeking 2-Applications: Rent seeking in practice (pp. 265279). Heidelberg: Springer.

Fischer, M., Kauder, B., Potrafke, N., \& Ursprung, H. W. (2017). Support for free-market policies and reforms: Does the field of study influence students' political attitudes? European Journal of Political Economy, 48, 180-197.

Gelb, A., Hillman, A. L., \& Ursprung, H. W. (1998). Rents as distractions: Why the exit from transition is prolonged. In N. C. Baltas, G. Demopoulos, \& J. Hassid (Eds.), Economic interdependence and cooperation in Europe (pp. 21-38). Springer. World development report background paper, The World Bank, Washington D.C., April 1996.

Harms, P., \& Ursprung, H. W. (2002). Do civil and political repression really boost foreign direct investments? Economic Inquiry, 40(4), 651-663.

Hefeker, C., \& Potrafke, N. (2021). Eine Erinnerung an Heinrich W. Ursprung. Perspektiven der Wirtschaftspolitik (in press). 
Hillman, A. L., \& Ursprung, H. W. (1988). Domestic politics, foreign interests and international trade policy. American Economic Review, 78(5), 729-745. Reprinted in: J. P. Neary (Ed.) (1995), International trade (volume 1, chapter 28), Edward Elgar; T. Brewer (Ed.) (1999), The globalization of the world economy: Trade and investment policy (pp. 470-486), Edward Elgar; W. J. Ethier \& A. L. Hillman (Eds.) (2008), The WTO and the political economy of trade policy (pp. 99-115). Edward Elgar.

Hillman, A. L., \& Ursprung, H. W. (1992). The influence of environmental concerns on the political determination of international trade policy. In K. Anderson, \& R. Blackhurst (Eds.), The greening of world trade issues (pp. 195-220). University of Michigan Press. Invited paper for a conference organized at the GATT (replaced by the WTO).

Hillman, A. L., \& Ursprung, H. W. (1993). The multinational firm, political competition, and international trade policy. International Economic Review, 34(2), 347-363.

Hillman, A. L., \& Ursprung, H. W. (1994). Greens, supergreens, and international trade policy: Environmental concerns and protectionism. In C. Carraro (Ed.), Trade, innovation, environment (pp. 75-108). Springer.

Hillman, A. L., \& Ursprung, H. W. (1996). The political economy of trade liberalization in the transition. European Economic Review (papers and proceedings), 40, 783-794.

Hillman, A. L., \& Ursprung, H. W. (1999a). Foreign investment and endogenous protection with protectionist quid pro quo. Economics \& Politics, 11(1), 1-12.

Hillman, A. L., \& Ursprung, H. W. (1999b). What is special about endogenous international trade policy in transition economies? In M. I. Blejer \& M. Škreb (Eds.), Balance of payments, exchange rates, and competitiveness in transition economies (pp. 255-282). Kluwer Academic Publishers.

Hillman, A. L., \& Ursprung, H. W. (1999c). The trials and tribulations of banking in transition economies: A political economy perspective. In M. I. Blejer \& M. Škreb (Eds.), Financial sector transformation: Lessons from economies in transition (pp. 132-149). Cambridge University Press.

Hillman, A. L., \& Ursprung, H. W. (2000). Political culture and economic decline. European Journal of Political Economy, 16, 189-213. Reprinted in: R. D. Congleton, A. L. Hillman, \& K. A. Konrad (Eds.) (2008). Forty years of research on rent seeking 2-Applications: Rent seeking in practice (pp. 219-243). Springer.

Hillman, A. L., \& Ursprung, H. W. (2016a). Where are the rent seekers? Constitutional Political Economy, 27(2), 124-141.

Hillman, A. L., \& Ursprung, H. W. (2016b). Academic exclusion: Some experiences. Public Choice, 67, $1-20$.

Hillman, A. L., \& Ursprung, H. W. (2020). Investigation in search of truth. Public Choice, 186(3), $223-228$.

Hillman, A. L., Hinds, M., Milanovic, B., \& Ursprung, H. W. (1997). Protectionist pressures and enterprise restructuring: The political economy of trade policy in transition. In A. Razin \& H.-J. Vosgerau (Eds.), Trade and tax policy, inflation and exchange rates (pp. 215-243). Springer.

Kauder, B., Potrafke, N., \& Ursprung, H. W. (2018). Behavioral determinants of proclaimed support for environment protection policies. European Journal of Political Economy, 54, 26-41.

Krapf, M., Ursprung, H. W., \& Zimmermann, C. (2017). Parenthood and productivity of highly skilled labor: Evidence from the groves of academe. Journal of Economic Behavior \& Organization, 140, $147-175$.

Lindov, D. (2020). Teachers and politics. European Journal of Political Economy, 64, 101902.

Lindov, D., \& Ursprung, H. W. (2021). Does having children create a glass ceiling for women with high-profile career positions? In D. Lindov, Three essays on some unsettled questions of political economy. PhD thesis, chapter 2. University of Konstanz.

Potrafke, N., \& Ursprung, H. W. (2012). Globalization and gender equality in the course of development. European Journal of Political Economy, 28(4), 399-413.

Potrafke, N., Rösch, M., \& Ursprung, H. W. (2020). Election systems, the "beauty premium" in politics, and the beauty of dissent. European Journal of Political Economy, 64, 101900.

Schulze, G. G., \& Ursprung, H. W. (1999). Globalisation of the economy and the nation state. World Economy, 22(3), 295-352.

Schulze, G. G., \& Ursprung, H. W. (2001). Globalization and the environment. Oxford University Press.

Ursprung, H. W. (1990). Public goods, rent dissipation, and candidate competition. Economics \& Politics, 2(2), 115-132. Reprinted in: R. D. Congleton, A. L. Hillman, \& K. A. Konrad, (Eds.) (2008). Forty years of research on rent seeking 1-Theory of rent seeking (pp. 329-346). Springer.

Ursprung, H. W. (1991). Economic policies and political competition. In A. L. Hillman (Ed.), Markets and politicians: Politicized economic choice (pp. 1-25). Kluwer. 
Ursprung, H. W., \& Wiermann, C. (2011). Reputation, price, and death: An empirical analysis of art price formation. Economic Inquiry, 49(3), 697-715.

Ursprung, H. W. (2012). The evolution of sharing rules in rent seeking contests: Incentives crowd out cooperation. Public Choice, 153(1-2), 149-161.

Ursprung, H. W. (2021). Jane beats them all: Price formation and financial returns to investing in rare books. European Journal of Political Economy, 28(4), 399-413.

Publisher's Note Springer Nature remains neutral with regard to jurisdictional claims in published maps and institutional affiliations. 